\title{
Unfamiliar Voices: \\ Harmonizing the Non-Socratic Speeches \\ and Plato's Psychology \\ Jeremy Reid
}

While the Symposium is often praised as a literary masterpiece, the logic of its overall construction remains a deep puzzle. Why are these seven speeches singled out from the other speeches delivered that night, and why are they taken to be the ones "worth remembering" (I78a)? Why do they proceed in the order that they do, and what is the relationship between what Socrates says and what everybody else says? These questions cause the Symposium to be a curious and problematic text: what are we to make of Plato speaking with all these unfamiliar voices?

Here I will explore the thesis that the first four speeches of the Symposium are propaedeutic for philosophy. I argue that the concerns raised in the early speeches highlight features of Plato's psychology and aspects of his education program that are more fully developed in the Republic. As the Republic also contains a philosophical ascent, the upshot for this reading of the Symposium is that we can see consistency across these dialogues insofar as both ascent passages are preceded by discussions that reflect concerns about education and character. In particular, Plato highlights four psychological features that are necessary for the soul to make progress on the ascent: firstly, it must have strong spirited capacities; secondly, it must be lawful and aim at virtue; thirdly, its various opposing elements must be harmonized; finally, its appetites must be minimized and orderly. ${ }^{\mathrm{I}}$ I contend that these four goals of education correspond to the first four speeches of the Symposium and that philosophical progress will not be possible without these psychic qualities.

\footnotetext{
I Plato has grouped these phenomena according to a tripartite schema in the Republic, which might suggest that the psychology implicit in the Symposium must also be tripartite, but the evidence for such a claim, though suggestive, is underdetermined. See Brickhouse and Smith 2012 for how Socratic psychology accounts for the appetites and passions, and Sheffield 2006: Appendix.
} 
The division of the speeches into a group of four and a group of three is suggested by the text. Before beginning his encomium, Agathon reflects on the previous speeches:

All those who have spoken before me did not so much celebrate the god $[E r \bar{s}]$ as congratulate human beings on the good things that come to them from the god. But who it is who gave these gifts, what he is like (hopoios de tis) - no one has spoken about that. ${ }^{2}$ (194e)

What unifies the early speeches is that they discuss the effects of erōs rather than its nature. Socrates approves of Agathon's observation (I99c, 20Id-e) and Diotima's speech is in part structured around this distinction between the nature of erōs and its effects (206b). I contend that the effects for which each of the early speakers praise Erōs are related to goals of Plato's education program in the Republic; thus, we are benefitted by Erōs insofar as his effects improve our soul. For each of the early speeches, I will first highlight features of the account of education and psychology in the Republic, and then show how these relate to the characterization of the speakers and the content of their speeches. I will end by suggesting how we might understand the characterization of Agathon and Alcibiades in light of this discussion of education: Agathon shows potential for philosophy whereas Alcibiades serves as a warning for those who attempt philosophy without a harmonized soul. ${ }^{3}$ So with this general structure in mind, let us turn now to the propaedeutic thesis and consider whether the same psychological concerns that shape the discussion of education in the Republic are present in the Symposium.

\section{Phaedrus and Spirited Motivations}

The Guardians of Kallipolis receive an extensive education designed to develop their characters and prepare them for dialectic. Plato's education program is notoriously demanding and only a small number of the Guardians will complete all the stages that qualify them to be

\footnotetext{
2 All translations are from Cooper 1997, with modifications.

3 This division of the dialogue's speeches is fruitful for understanding the unity of the last three speeches. What Agathon says about erōs' nature is false and he is promptly refuted, suggesting a state of ignorance; Socrates, having learned from Diotima, provides a true account of erōs' nature, its powers, activities, and effects such that one gains understanding, leading us up the ascent to the Forms and thus the grounds of knowledge; Alcibiades swears that he'll only tell the truth and asks Socrates to correct him if he says anything that is false, but he shows the characteristic instability of those with untethered true beliefs, vacillating between the views of the many and what Socrates told him.
} 
philosopher-rulers. In the Republic, education promotes virtue and character virtue is explained (partly) in terms of the tripartite soul and the relations between its elements. Much of the discussion of education reflects Plato's novel introduction of the spirited or thumoeidic part of the soul, explaining its nature, objects, characteristic activities, and correlative character types.

The Guardians need to be educated to have a strong spirited part so that they can become courageous (375a-b, 386a, 395c, 399a-b, 4IOd, $429 \mathrm{~b}-43 \mathrm{Ob}$ ). When the spirited part is strong, the Guardians will have a reliable sense of shame and honor. Socrates tells us that they will feel shame at shameful things and shameful actions, which will prevent them from associating with such objects or acting in such ways (378b-c, 395e-396a). Moreover, Guardians will be taught to honor the gods and their parents (386a). Because they are taught that the gods honor virtue in this life and in the afterlife, they will be unafraid of death and Hades (386b, 387d). Their strong desire for honor and love of the fine (kalon) will cause them to aim at noble actions, victory, and honor, especially honor from warfare and military prowess $(440 \mathrm{C}-\mathrm{d}, 549 \mathrm{a}, 58 \mathrm{rb}$ ). This makes the Guardians the best fighters, and causes them to preserve the prescriptions of reason in the face of pain, trial, and temptation $(442 \mathrm{~b}-\mathrm{c})$.

In the Symposium, Phaedrus is characterized in spirited terms and his speech is replete with thumoeidic content. ${ }^{4}$ Firstly, he is introduced as being indignant that the god Erōs has not received sufficient honor and so wants to hear encomia to him $(\mathrm{I} 77 \mathrm{a}-\mathrm{c})$. Elsewhere in the Platonic corpus, Phaedrus is characterized as being particularly eager to hear speeches from famous orators though he is an amateur himself (Phdr. 228a-c; Prot. 315c). This corresponds to the timocratic, spirit-ruled youth in the decline of Kallipolis, who would "love to listen to speeches and arguments, though he's by no means a rhetorician" (548e). Thus while Phaedrus' characterization is thin, the descriptions we do have suggest he has a spirited nature.

This characterization is confirmed by the content of his sparse and short speech. Phaedrus starts the proceedings by praising the guidance that erōs provides: Erōs instills an especially strong sense of shame for shameful things and love-of-honor for fine things in the lover and the beloved ( $178 \mathrm{~d})$. The idea is that those in love cannot bear the thought of being thought ill of by the person whom they love and this stops them from doing shameful things. Love, then, can act as a safeguard against our

4 Hobbs 2000: 25I-2, Wilburn 20I5: 22 n38. 
excessive or bad inclinations. However, erōs also inspires lovers to do great and honorable things, which make lovers the best and most courageous fighters (I79a-b). Furthermore, gods honor lovers who do great deeds for love and punish those who do not - this is why Alcestis and Achilles are rewarded and Orpheus, made soft by his kithara playing, is punished (I79b-I8ob). ${ }^{5}$

Phaedrus' speech is easy to pass over quickly, but it is striking how many times shame and honor feature in the speech; moreover, there is a strong emphasis on acts of courage and military prowess, especially in his use of the Theban Band (I78e-I79b) and Achilles (I79e-I8oa). Phaedrus also highlights the motivational force that erōs provides in the performance of great deeds for others (I78e-180a). He thus concludes that "of the gods, erōs is the most ancient, most honorable, and most powerful for the acquisition of virtue and happiness for men" (I8ob). It is notable though that we have no reason to think that Phaedrus' conception of virtue extends beyond courage or that his conception of happiness extends beyond receiving honor. His conception of value is thus limited by spirited concerns. Stepping back, the point of Phaedrus' speech is that erōs effectively engages and develops spirited capacities: few things can make us more ashamed of our bad behavior than the disappointment or disapproval of our lover, and few things motivate us to do great and wonderful deeds more than love. Thus, Erōs benefits us by activating and fostering these psychological forces.

Because the Republic makes it clear that spirit ought to be fostered, the effects Phaedrus praises improve our character along this dimension. This needn't entail that taking a lover is just as good as the education system of Kallipolis for developing spirit, but it provides grounds for thinking that what Phaedrus details is an image or imitation of the ideal education. ${ }^{6}$ Lovers do not always reliably or perfectly cultivate our spirited capacities, but they do often improve and activate them - and in noticing this, Phaedrus is right to think that Erōs benefits us.

\section{Pausanias and Lawfulness}

It is unsurprising that for the education system in Kallipolis to work, its prescriptions have to be followed strictly. But it is notable that the

\footnotetext{
5 For the natural antagonism between spirited types and musical training (especially the deleterious effects of stringed instruments) see Rep. 399d-e, 549b.

${ }^{6}$ For the early speakers as "shadow lovers" who provide images of virtue and happiness, see Sheffield 2006: chapter 7 .
} 
education system is repeatedly described in terms of laws or conventions (nomoi) and that the Guardians take these to be an authoritative guide to how they should think, feel, and act (at least in the early stages of their education). ${ }^{7}$ Even in childhood games and in musical practices, there is to be no innovation or anything done against the established order so that lawfulness can be firmly established in the Guardians $(424 \mathrm{~b}-425 \mathrm{a})$. Plato is explicit that strict lawfulness is necessary for education to work (427a). Indeed, lawfulness is the goal of education: Socrates says that education in music and gymnastics was for "nothing other than this," namely, the inculcation of the laws, so that the Guardians "would absorb the laws in the finest way possible, just like a dye" (430a). Just as a well-prepared wool will absorb a dye so thoroughly that "no amount of washing. . can remove it," the Guardians are to internalize the laws completely and permanently that they preserve it through "such extremely effective detergents as pleasure, pain, fear, and desire" (429c-43ob).

The emphasis on lawfulness in the discussion of the early education is further confirmed in later passages. The decline of Kallipolis is characterized repeatedly in terms of a breakdown of the established laws at each stage (546d, 550d, 572c-d, 574e), where rulers "[run] away from the law like boys from their father" ( $548 \mathrm{~b}$ ). Socrates also describes good pleasures and desires as lawful $(57 \mathrm{Ib})$ and bad ones as lawless $(572 \mathrm{~b})$. Law is further connected with the prescriptions of reason in that "whatever is most distant from reason [is] also most distant from law and order" (587a). Law is called a kind of external reason that establishes a constitution in the soul, fostering the best part in it and acting as the ally of everyone (590d). Law also works together with reason to fight against the desires and reactions of the lower part of the soul, especially grief and pleasure $(604 a-c)$. Finally, there is evidence suggesting that law's influence extends well into philosophical education: Socrates says that only the most steadfast in preserving what law had laid down are fit for dialectic $(537 \mathrm{c}-\mathrm{d})$ and that dialectic has received a bad reputation because of those who do it badly now, on account of their filling it with lawlessness (537e-539a). Cultivating lawfulness is thus an integral part of Platonic education. ${ }^{8}$

\footnotetext{
7 Annas 20I0, 2013 and forthcoming; Lane 2013.

8 Becoming lawful may be important in the development of reason. Law reliably gives citizens true beliefs about how they ought to act (Stat. 30ob), and deferring to law and to what is conventionally believed is better than thinking you know something when you don't (Phdr. 230a). This explains
} 
Returning to the Symposium, after some other speeches that Aristodemus couldn't remember ( $\mathrm{I} 8 \mathrm{Oc}$ ), Pausanias continues by elaborating on the theme of erōs as an important motivational and educational tool, but criticizes Phaedrus for not distinguishing between two types of erōs: one of which leads us well and produces beneficial dispositions in us, the other of which does not (I8ra). Pausanias subsequently separates Common and Heavenly Love (I8od). His main point throughout the speech is that Athenian laws and conventions allow lovers to love rightly and that what divides the two kinds of erōs is that heavenly love is lawful. Pausanias says that only Heavenly Erōs should be praised because only Heavenly Erōs benefits lovers and produces praiseworthy actions. He claims that one cannot determine in the abstract which actions are good and which bad because what matters is whether the action is done "finely and rightly" (I8Ia). But what makes an action right and fine is its being lawful. Thus good lovers act lawfully and bad lovers act hubristically. ${ }^{9}$

Indeed, Pausanias' focus on the importance of law has prompted one commentator to call him a "legal pedant." ${ }^{\text {"O }}$ Notice how Pausanias condemns those filled with Common Erōs:

All they care about is doing it. Whether they do it finely or not is of no concern. That is why they do whatever comes their way, sometimes good, sometimes bad; and which one it is, is incidental to their purpose (I8Ib).

These lovers behave indiscriminately as they have no consistent guide; rather, they are led by whatever happens to strike them - that is, depending on how things appear to them. This reliance on appearances could in turn lead them to ignore the limits determining what they ought and ought not to do. Now compare these lovers with those filled with Heavenly Erōs, who are not subject to the hubris of Common Erōs (I8Ic). Heavenly lovers recognize the limits on the actions they might perform and these limits are determined by law. While Pausanias thinks Athenian laws are basically good, good men make further laws for themselves to fill in the gaps and loopholes (I8re). This language of self-legislation bears strong similarities to the Republic, where Socrates says that it is not fitting to legislate every tiny detail for good men, as they will "easily find out for themselves whatever needs to be legislated about such things" $(425 \mathrm{~d}-\mathrm{e}) .{ }^{\mathrm{II}}$

why lawfulness is necessary for beginning dialectic - it provides the best set of beliefs and intellectual humility from which to start investigation. See also Annas forthcoming.

9 See Dover 1989: 34-39 for the relationship between hubris and law. Io Sheffield 2006: 222.

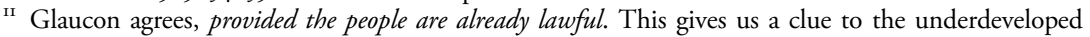
characterization of Pausanias. 
Thus, good lovers understand their actions in terms of law, are guided by law, and act willingly in accordance with it, whereas bad lovers are prone to transgress the law and need to be forced to follow it (I8Ie-I82a). In that sense, law determines what actions are shameful and honorable, what is to be done and what is not to be done.

It may be objected that in the Republic citizens are not obeying just any laws, but good laws - laws that aim at virtue in accordance with what is actually good and honorable, whereas Pausanias is talking about ordinary laws. But Pausanias thinks that Athenian and Spartan laws do in fact meet this higher standard and that is what justifies them. His defense of Athenian and Spartan laws has a Goldilocks structure: Elis and Boeotia are too hot in approving the taking of a lover in every case; Ionia and Persia are too cold in always considering it disgraceful; but Athens and Sparta get it just right in having complex laws, not always condemning nor always praising the taking of a lover ( $182 \mathrm{a}-\mathrm{I} 83 \mathrm{~d})$. Moreover, the Athenian laws "are designed to separate the wheat from the chaff, the proper love from the vile" (I84a) in that ultimately they "provide for only one honorable way of taking a man as a lover" (I84c). Thus Athenian laws result in honorable behavior and are a good standard for what is honorable.

Pausanias ends his speech by defending that Athenian laws are good because they approve of subjection (douleia) for the sake of wisdom and virtue: ${ }^{\mathrm{I2}}$

If someone decides to put himself at another's disposal because he thinks that this will make him better with respect to some wisdom or in any other part of virtue (kata sophian tina è kata allo hotioun meros aretēs), we approve of his voluntary subjection (ethelodouleia): we consider it neither shameful nor servile... When an older lover and a young man come together and each obeys the principle appropriate to him - when the lover realizes that he is justified in doing anything for a loved one who grants him favors, and when the young man understands that he is justified in performing any service for a lover who can make him wise and virtuous and when the lover is able to help the young man become wiser and better, and the young man is eager to be taught and improved by his lover - then, and only then, when these two principles coincide absolutely, it is fine for a young man to accept a lover. (I84C-e)

The pursuit of virtue determines when it is honorable to take a lover and this pursuit is so important that even if one of the parties is deceived about the character of their partner, their desire is of such a noble kind that

${ }^{12}$ This may seem shocking, but see Euthd. 282b; Crit. 5oe; Leg. 698a5-70Ic4, 715d, 762 e. 
their actions are still honorable (I85a-b). The cultivation of the soul thus has pride of place for Pausanias and its goal is wisdom and virtue. ${ }^{\mathrm{I}}$ Thus, because Athenian laws aim at this goal, lawful Athenian lovers act well and finely.

Pausanias' speech, therefore, focuses on lawfulness and the establishment of virtue as a goal. An important part of this conception is that lawful lovers are not merely guided by whatever appearances happen to strike them and deference to the law allows them to act well. ${ }^{\mathrm{I}}{ }^{4}$ Thus I contend that the moral to take from Pausanias' speech is that heavenly erōs benefits lovers by leading them to aim at wisdom and virtue in accordance with the law. Of course, Pausanias' own account of virtue and the role of reason looks thin and instrumental insofar as it results in what we might call "right action" but right action lacking a substantive philosophical justification. In that sense, like Phaedrus, he still only presents an image or imitation of the ideal education program, and Athenian laws will be in practice less beneficial than the laws of Kallipolis. But Pausanias has also expanded on Phaedrus' conception of virtue by making reference to wisdom, even if it is unclear whether he has more to say about what virtue and wisdom consist in. So, on the one hand, perhaps Pausanias does not help us much in moving beyond lawfulness itself as the standard of virtue, and maybe his lovers could only ever attain conventional virtue, participating in it "through habit and without philosophy" (Rep. 619c). ${ }^{\mathrm{Is}}$ On the other hand, insofar as he encourages lovers to be lawful for the sake of their aspirations to wisdom and virtue, there is no reason why their pursuit might not lead them beyond where Pausanias can guide them. At any rate, Pausanias' account is one which evidently needs to be supplemented, but lawfulness is an important stage in the development of character for Plato, and it confers substantial psychological benefits in the course of education.

\section{Eryximachus and Harmonizing Opposites}

In order to ensure that they do not become dominated by their spirited natures, the musical education of the Guardians also aims at bringing about a love of order and a harmony in their souls. This helps to make the

${ }^{13}$ Sheffield 2006: 6, I8-20.

${ }^{\mathrm{I}}$ Cf. Moss 2008, Carone 200I, and Ganson 2009 on reason as measuring appearances.

is Lawfulness might have been all that some thought virtue was (Prot. 326d-e). 
soul-parts an integrated whole, with the various potentially opposing elements working together as one.

Socrates is explicit that the education program is designed to harmonize the opposing gentle and spirited natures in the Guardians $375 \mathrm{~b}-\mathrm{c}$, 4IOe-4IIa). ${ }^{16}$ When this happens correctly, the harmony generated is primarily what moderation (söphrosune) consists in (389d, 430e, 43I $-432 \mathrm{a}, 442 \mathrm{c}, 443 \mathrm{~d}-\mathrm{e}, 59 \mathrm{Ic}-\mathrm{d})$; specifically, moderation is a kind of agreement (homonoia) between the parts of the soul (432a). Certain kinds of music produce moderation insofar as they exemplify these harmonies and establish order in the soul (399a-40oe). Musical education also causes the Guardians to love harmonious things wherever they find them and to hate disorderly and unharmonious things (402d). Socrates describes this in terms of love: "The right kind of love," he says, "is by nature the love of order (kosmiou) and beauty that has been moderated by education in music and poetry... [and] the right kind of love has nothing mad or licentious (akolasias) about it" (403a). This love of harmony also informs how the Guardians act, as actions that destroy the harmony of the soul are unjust and that actions that preserve it are just (443e).

Importantly, the Republic conception of psychic harmony is associated with medicine and natural science. Glaucon concedes that the justice of the soul and its harmony are goods in themselves when Socrates points out that this state is a kind of health (444d). Moreover, in motivating the goodness of psychic harmony, Socrates appeals to the fact that the technai aim at the harmony, grace, and rhythm that develop "in accordance with an intelligent plan" (40oe-40Ia). He goes on to claim that "our bodily nature is full of [these qualities], as are the natures of all growing things, for in all of these there is grace and gracelessness. And gracelessness, bad rhythm, and disharmony are akin to bad words and bad character, while their opposites are akin to and are imitations of the opposite, a moderate and good character" (40Ia). This is why training in music and poetry is so important for cultivating a harmonized soul: through noticing when "something has been omitted from a thing and when it hasn't been finely crafted or finely made by nature," the Guardians will come to form a conception of harmony and order, and then use that to inform their own actions (4OId-402a). Just as they will notice when a note is missing from a musical chord, they will notice deficiencies in the city and soul that need counter-balancing. Socrates explains the theoretical basis for this when he says that "excessive action in one direction usually sets up a reaction in 
the opposite direction. This happens in seasons, in plants, in bodies, and last but not least, in constitutions" (563e). Thus this conception of health and the harmonizing of opposites is a crucial piece of the Republic's argument, and its psychological import grounds much of the education program.

Eryximachus' characterization and speech in the Symposium share many similarities on these points. Firstly, he is a doctor, so we should be alert to the parallels between his concerns about bodily health and those in the Republic. Furthermore, Eryximachus acts as a kind of doctor for Agathon's symposium in that he keeps order and prevents the party from declining into intemperance at a number of points: he is the one who recommends that the guests should refrain from heavy thinking in light of the previous night's excesses ( $176 \mathrm{c}-\mathrm{d}$ ), and then suggests that they send away the flute girl so that they can spend the night listening to speeches (176e-177e); when Aristophanes gets the hiccups and disrupts the order of the speeches, Eryximachus both remedies Aristophanes' health and takes his place as speaker (I85c-e); finally, when an already drunken Alcibiades starts to drink still more, Eryximachus is the one who chastises his impropriety and suggests that he give an encomium to Socrates instead (2I4b-e) ${ }^{17}$ The resident doctor thus wards off intemperance and maintains order in the Symposium.

Eryximachus' speech begins by expanding on Pausanias' distinction between Common and Heavenly Eross, explaining that both forms of love not only occur with respect to human souls (psuchais) but also occur with respect to animals and plants and in all the things that are (186a). Beginning with the human body, Eryximachus claims that in healthy and diseased constitutions, there are different forms of erōs: unhealthy erōs comes from a constitution which is dissimilar (anomoion), which generates a desire and love for things which are themselves dissimilar (I86b-c). The knowledge and skill of the doctor consists in knowing what ought to be "encouraged and gratified" for the sake of health, and what ought to be "frustrated and rebuffed" (I86c). Specifically, Eryximachus says that a physician's job is to make the opposites in the body friends (phila), and share love (eran) and agreement (homonoian), where the harmonized opposites are hot and cold, bitter and sweet, wet and dry, and everything else like this (186d-e). Already this is similar to the Republic's conception of health in that it involves generating agreement and harmony between opposing elements. 
Eryximachus then seems to commit a baffling non sequitur by saying that in the same way that medicine is guided by love, so too are gymnastics, farming, poetry, and music (I87a). He later claims that love also controls the seasons (I88a), astronomy (I88b), and divination (I88c-d). Although this expansion of the theory has been the target of criticism (and Eryximachus probably does claim more than he can justify), each of these fields includes examples of generating harmony between opposites. ${ }^{\text {I8 }}$ Because the music analogy is most fully explained, let us start there.

The passage begins by quoting Heraclitus: "being at variance with itself is in agreement with itself. . like the attunement of a bow or a lyre." Eryximachus interprets Heraclitus to mean that "an expert musician creates a harmony by resolving the prior discord between high and low notes" (I87a-b). In music, as soon as a note moves from the tonic, a kind of dissonance is created - but music isn't about avoiding such dissonances so much as shaping these dissonances into an orderly whole. So too with rhythm (I87c): music and poetry do not avoid fast and slow rhythms, but order them systematically. Eryximachus' point is not that we should pull the high and low notes into a less extreme middle pitch, or fast and slow rhythms into a homogeneous andante - that wouldn't make sense of his examples - his claim is that the various opposites need to be ordered so that harmony and agreement between them are created, both synchronically and diachronically (I87c).

Eryximachus then discusses the effects of music on audiences and performers, which further emphasizes the connection between musical structures and the desires in those habitually exposed to them (I87c-d). This interpretation goes some way in explaining his other applications: firstly, the doctor is able to show how appetites can be gratified without slipping into intemperance (akolasias) or disease (nosos), by drawing attention to the various opposites in diet (hot/cold, dry/wet, sweet/bitter) and regulating the excess of one through the supplementation of the other (187e). His point is this: given the kind of being that we are, we are going to experience appetites, bodily lacks and excesses - what's important is that we satisfy them in an orderly way that leads to a healthy state. Similarly, when the seasons are governed by the good kind of erōs, they are balanced and in harmony, causing plants and animals to be in good health, whereas the bad kind of erōs in seasons kills and destroys living things through extreme conditions and disease (I88a-b). Presumably this also explains the

${ }^{18}$ See Sheffield 2006: 2I-22 and Trivigno, Chapter 3 in this volume.

I9 Cf. "stretching and relaxing" and "slackening and loosening" the soul (Rep. 4IIe, 44Ie, 590b). 
earlier reference to the two kinds of erōs being relevant for the skill of farming: farmers must know how to counterbalance the natural excesses of the weather and seasons. Eryximachus' extension of this theory to astronomy is puzzling, but plausibly the idea is that orderly heavenly motions cause orderly seasons and disorderly heavenly motions cause disorderly seasons, so he is pointing to a higher cause (I88b). Finally, Eryximachus applies the theory to divination in urging us to gratify the orderly kind of love with respect to the gods (I88c). This also need not be as overreaching as it seems, considering that much of Greek religious practice was about performing the right kind of ceremonies at the right times in order to establish friendship and harmony between gods and mortals.

Eryximachus' speech thus bears strong resemblances to the passages on psychic harmony and health in the Republic insofar as it endorses a picture of health that consists in the harmonization of opposites, and in that it gives an explanation of unhealthy love for bad things in terms of its being caused by an unhealthy and out-of-balanced subject. There are, however, two notable limits to Eryximachus' speech. Firstly, in the Republic, psychic health explains bodily health and is thus prior to it (408d-e). Eryximachus seems to leave open the possibility that, for example, a bodily remedy will bring about the good kind of erōs in a person and change their desires. Plato is more careful in the Republic as he has a richer psychological account to explain how bad desires come about. Secondly, Eryximachus claims that everything that is partakes in or is governed by erōs (I86b). That all things partake in opposites might be true of most sensible particulars, but certainly not of everything that is - the obvious counterexample being the Forms. Therefore Eryximachus' speech oversteps with respect to metaphysics, though its implicit materialism might be appropriate for explanations in Platonic physics.

At any rate, the claims Eryximachus makes about how Erōs benefits us by bringing about harmony between our opposing elements are in accordance with Plato's view of education. The establishment of psychic harmony will allow us to gratify our appetites in an orderly fashion and will draw us towards the right objects for our psychic and bodily health. So if Eryximachus is right that Erōs improves us by bringing about harmony between the opposing elements in us, such a result would be an image or imitation of the moderation instilled by the education program of Kallipolis, improving our body and soul with respect to their health and integrity. ${ }^{20}$

${ }^{20}$ This reading may help us understand why the order of speeches is wrong ( $185 \mathrm{c}-\mathrm{d}$ ). Eryximachus makes a number of references to the appetites, but Plato has not yet given us an adequate description of the appetites, so Eryximachus' speech relies on conceptual resources that have not 


\section{Aristophanes and the Appetites}

Though not introduced until late in Republic IV (437b), the appetitive part of the soul lurks threateningly throughout the earlier discussion of education: the Guardians of Kallipolis are not allowed to own property, accrue money, or even touch gold and silver (4I7a); the Homeric epics are purged of references to Achilles loving money and suggestions that virtue consists in finding effective means to acquire tripods (390e-39re); the juicy passages about Zeus' sexual exploits are likewise swiftly athetized (39ob-c), and even the passages on feasting and drinking are removed, lest young people think that this behavior is consistent with moderation $(390 \mathrm{O}-\mathrm{c})$. Plato is explicit that excessive pleasures and appetites are incompatible with moderation and virtue, and are closely connected with violence (bubris) and licentiousness (akolasia; Rep. 403a, 408b, 43Ib, 560e, 572c; Phdr. 238a, 250e, 253e, 254e, 255e, 256c; Gorg. 493b-494a, 505b, 507e, 525a). These measures are thus designed to keep the appetites as small and restrained as possible. We learn more about the appetites and how they are corrupted in Republic VIII-IX. Before Kallipolis' decline, appetitive desires are weak and few in the citizens, and are limited to necessary and natural objects (558d-56Ic, 57Ib-d). This result is attributed to the education system acting in conjunction with the laws $(57 \mathrm{rb})$. But once the characters of the rulers worsen and the laws are changed, new appetites arise in the city, and fulfilling these appetites eventually becomes the sole object of pursuit for the tyrant, who is controlled by a "violent crowd of desires" $(572 \mathrm{~d}-575 \mathrm{a}){ }^{2 \mathrm{I}}$

Before returning to the Symposium, it is worthwhile to explore briefly what an appetite is in the Republic. In Book IV, we are told that each appetite is a desire for a natural object (437e), which is pleasant when satisfied. Plato is clear that the natural object is desired as the natural object and not as the natural object plus goodness or some other modifier (438a-439d). Furthermore, what is most one's own (oikeion) is also most pleasant:

Can't we confidently assert that those desires of even the money-loving and honor-loving parts that follow knowledge and argument and pursue with their help those pleasures that reason approves will attain the truest

yet been provided. Hence, his speech comes one too early. The given order heightens the dramatic arc and tempo of the work by putting the amateur speech-makers before the experts, but, strictly speaking, their logical content requires that Aristophanes comes before Eryximachus.

${ }^{21}$ Wilburn 20I4. 
pleasures possible for them, because they follow truth, and the ones that are most their own (oikeias), if indeed what is best for each thing is most its own (oikeiotaton)? (586e)

Plato uses this claim to argue that because the pleasures of the rational part of the soul are the most oikeion, they are also the most pleasant (586d-588a). Moreover, it is important that all of the parts of the soul do best with respect to their own oikeion objects and thus their own pleasures when they are guided by reason, because the pleasures pursued when reason rules are true and the most oikeion; that is to say, appetite and spirit are both better off when they are guided by reason, even on their own terms. Thus, there is a strong connection between Plato's conception of the appetites, desire, the oikeion, and pleasure in the Republic.

It is fitting for Aristophanes to speak about the appetites in the Symposium. For Plato's subject is erōs, and sexual desire is an important species of erōs. So to set the scene, Aristophanes responds to Eryximachus' speech by making a crude joke: if he was returned to health from his hiccups by sneezing, then is the orderly sort of love in the body created by the same sort of thing that a sneeze is (I89a) ?22 The mockery rests on an oversimplification: the diseased state of erōs is just an excess of semen - get rid of that and health is returned. We have been prepared for such baseness though: Aristophanes needs no introduction regarding the content of his comedies, but even in the dialogue he is said to "think of nothing but Dionysus and Aphrodite" (I77e), is singled out for his particularly excessive drinking the night before (176b), and gets the hiccups because he "probably stuffed himself again" (I85c) which causes him to speak out of order. Aristophanes, then, is a paradigm of the disorderly appetitive character.

This reading is supported by how Aristophanes starts his speech, which has as its stated topic human nature (phusis) and what happened to it (its pathèmata). Plato can never resist a pun and this one is especially good: on the one hand, Aristophanes' speech is about how we used to be spherical conjoined humanoids who were split into two by the gods, thus creating our needy nature and desire to be united with our other halves; on the other hand, pathemata is one of Plato's terms for the appetites (Rep. 439d, Tim. 69c-d), and phusis has valences regarding sex and genitalia. ${ }^{23}$ Thus, Aristophanes basically announces that his subject is sex and appetitive desire, and I contend that we should read the speech

\footnotetext{
22 Specifically, by certain sounds and itchings. Greeks used itching, scratching, tickling as euphemisms for masturbation and sexual lust. See Dover 1989: 99, I23, I37.

23 See LSJ "phusis," section VII; Henderson r99I.
} 
on these two levels throughout: in particular, we should understand the humanoids as a metaphor for the appetites and the gods as a metaphor for reason.

Things used to be different, Aristophanes tells us. Human beings were once spherical conjoined pairs (I89e-190a) and we came as either a pair of males, a pair of females, or an androgynous combo (190b). We rolled around from place to place, our spherical motion imitating that of the heavens. These original humans were no mean things: they were so strong and ambitious that they tried to overthrow Olympus - the paradigm of hubris - and the story about the Giants was really about them (19ob-c). But Zeus and the gods could not simply destroy these humanoids as they were required for worship and sacrifice (nourishment), but neither could they "let them run riot," so they came up with a plan "to stop their misbehaving" (akolasia, I90c, cf. I87e). Zeus then cut all the humans in two and Apollo rearranged their features (I9od-I9Ia). But this caused yet more problems as the humans only desired to embrace their other halves, so they neglected to eat and eventually died (I9Ia-b, cf. Phdr. 259b-c). Zeus solved this problem by moving the genitals and inventing sex, so that after orgasm "they could stop embracing, return to their jobs, and look after their other needs in life" (I9Ic-d).

Erōs then, according to Aristophanes, is the desire to re-unite ourselves with our natural other half and the desire is (momentarily and partially) fulfilled by achieving orgasm with one's partner. This would be much the same point as the joke from the start of the passage, but there's more to it than that, as even for Aristophanes erōs is about more than satisfying sexual desire (192c-d). Sex is an expression of wanting to become unified with our original halves, but it falls short. If Hephaestus were to offer to put us back together with our lover, none of us would refuse such an offer as it is that which we have always desired (epethumei, 192d-e). "Love' is the name for the desire and pursuit of the whole" (tou holou oun tèi epithumiai kai dioxei erōs onoma, 192e-193a). This is why we should take a lover: it is the fulfillment of our natural desire to be whole again (193c). The desire for wholeness is likely to be frustrated in these bodies - "Love does the best it can for the time being: he draws us towards what belongs to us" (eis to oikeion agōn, I93d) - but if we are pious, we will perhaps be restored to our original nature.

Notice that Aristophanes' preferred word for desire is epithumein, and recall that, in the Phaedrus, Republic, and Gorgias, the appetites are frequently described as intemperate (akolastos) and hubristic; similarly, in the decline of Kallipolis, the appetites seek to overthrow the rule of 
reason in the soul just as the humanoids seek to overthrow the gods (Phdr. 253e-254e; Rep. 442a-b, 444b; Tim. 9Ib). Moreover, an appetite is a lack with a natural and oikeion object which it desires; in the myth we were cut in half and were not happy until we found that which made us whole, and so too our appetites are each continually unhappy until they find satisfaction in their desired object. But it is the nature of appetites not to stay satisfied for long: our bodies are continually depleting and even the satisfaction of sex is taken as only a rough approximation of its true desire, which is total fusion with its oikeion object. Compare Plato's point about appetitive desires always being in flux: even the satisfaction from eating and drinking is only momentary, as the process of filling or emptying never ends in these bodies (Rep. 585e-586a; Gorg. 493d-494b). We do, however, need the appetites to continue living. ${ }^{24}$

But how does Aristophanes' speech give us a picture of the education of the appetites? How does Erōs benefit us with respect to that part of the soul? Firstly, we know that the appetites are needy but also that they have tunnel-vision: each appetite can only care about one thing, its natural oikeion object (recall Rep. 439a-b). Given the hubristic nature of the appetites and their pretensions to overthrow the gods, Aristophanes says we need to be careful to "keep order before the gods" lest we be "split in two again" (193a). Thus the gods should be treated with reverence so that humans can be made whole, "and we will [be made whole again], if Love is our guide and commander. Let no one work against him" (193b). Aristophanes might here be hinting at the same lessons from the Phaedrus and the Republic that the appetites need to be guided and restrained by something external to themselves to remain in a good state. Because the appetites cannot co-ordinate their efforts themselves and are naturally prone to excess, limit has to be placed on them and deliberation done for them by a superior faculty (Rep. 432a, 444a-b, 586e); for example, in Republic IX, the democratic man uses reason to determine the greatest compossible set of his desires he can fulfill $(56 \mathrm{Ib}-\mathrm{c})$. Moreover, increasing the number of desires competing for different objects would cause more frustration and pain

\footnotetext{
${ }^{24}$ See Obdrzalek in this volume for the claim that Aristophanes' humanoids work at a low-grade cognitive level, as they lack logos and cannot express what they want. For the appetites lacking logos, see Ganson 2009 and Moss 2008. Plato is careful in his choice of evaluative language: Aristophanes speaks of what makes us (our appetites) happy (eudaimōn, I93c-d), but says nothing about the relationship between the oikeion and the good. This may be why he objects to Socrates' criticisms (205e, 2I2C): as there is an important relationship between the oikeion and the good.
} 
in the appetitive part of the soul, especially as the desires became stronger and harder to fulfill. Plato thus urges us to restrain our appetites to those that are natural and necessary so that the appetitive part of the soul remains orderly (57Ib, $589 \mathrm{~b}) .{ }^{25}$

But why think that this subordination of the appetites to reason and spirit leads to the appetites being fulfilled and made whole? Well, for one, the appetites have no internal way of resolving conflict. If somebody is hungry but also wants sex, there is no way for the appetites to adjudicate this dispute on their own terms: each object is oikeion but they might not both be honorable or good. Another way we might think about Plato's point here is that the appetites aren't capable of determining the details of what they really want and this ends up making them worse and more intense; for example, our hunger for pastries only ends up making us sick and hungrier later because it cannot distinguish between the food it really needs and the food it wants. Thus the appetites individually and collectively have a better chance of getting fulfilled if they submit to reason. Of course, we cannot hope to have our desires completely fulfilled all the time, but perhaps that is why Aristophanes concludes by saying that love "does that best that can be done for the time being: he draws us towards what belongs to us" (193d). This reading makes a bizarre speech stranger still, but I contend that the appetitive references are too numerous to be merely accidental, especially when put into the mouth of Aristophanes.

\section{Agathon and Alcibiades: Having a Soul Fit for the Ascent}

If this reading of the early speeches is promising, then both the Republic and the Symposium contain discussions of education before the ascent. Why? The Republic seems to suggest that the education system will implant something like demotic virtue into the Guardians $(429 \mathrm{c}-43 \mathrm{Oc}$, 522a). ${ }^{26}$ Elsewhere, Plato raises the possibility that lower-grade character virtue can be found in people who were not raised in a perfect education system (Rep. 619c; Phd. 68d-69c, 82a-b). Perhaps in the Symposium too, then, the beneficial effects detailed in the early speeches would (when taken collectively) result in demotic virtue in a person, improving the soul in various ways but without philosophy. Thus, I will end by suggesting that cultivating demotic virtue and improving one's soul along these four dimensions is necessary as a propaedeutic for the ascent.

${ }^{25}$ Cf. Brennan 20I2: I04-6. $\quad{ }^{26}$ Vasiliou 2012. 
The early education of the Guardians ends in love of beautiful boys, but, just as in the Symposium ascent, they quickly move beyond bodies in their love of beauty (403b-d). Thus, early education gets us to the bottom of the ladder in both dialogues, and, as Socrates states, "a naturally virtuous person, when educated, will in time acquire knowledge of both virtue and vice. And it is someone like that who becomes wise, in my view, and not the bad person" (Rep. 409d-e). Education prepares the soul for philosophy and one cannot make progress on the ascent without a harmonized soul.

In the Republic, Plato's explanation for why unjust souls cannot make philosophical progress is that their erōs is channeled away from philosophy and directed towards lower ends $(485 \mathrm{~d}-\mathrm{e})$. This prevents the soul from moving to and focusing on higher objects, as lower desires drag the sight of reason down like "leaden weights" to focus on base sensible particulars (518e-519b, 572a). The prime example of this phenomenon of being dragged from philosophy by spirited and appetitive desires is Alcibiades (490e-495b). ${ }^{27}$ Only those with just souls have the necessary psychic stability to keep their erotic resources channeled consistently towards reason's desires, leaving it free to do philosophy and contemplate intelligible objects.

While I cannot defend this fully, the later speeches of the Symposium can be seen as dramatizing the relationship between character and philosophical progress. Agathon claims to speak about the nature of erōs, but almost everything he says about erōs is false insofar as he attributes to Erōs the qualities that Erōs in fact desires; he is thus refuted by Socrates. ${ }^{28}$ But notice how smoothly the refutation goes: Agathon is not angry that he is being corrected by Socrates and he graciously admits that he didn't know what he was talking about (20Ib). Indeed, Agathon's refutation is one of the least antagonistic in the Platonic dialogues. His grace in responding to refutation may give us a reason to think that the real reason Socrates is flirting with Agathon is not (just) because he is physically beautiful, but because he has a beautiful soul and shows potential for philosophy (Gorg. 458a-b; Tht. 15rb-d). Note that Socrates puns at the start of the dialogue that they are going to a

\footnotetext{
27 Wilburn 20I5.

28 Note Agathon's method of inquiry is correct and shows his potential for philosophy (Sedley 2006), but he doesn't know what erōs is. There is another conceit here, as not only is Agathon Pausanias' beloved (rather than lover) but his name means "Good," so Plato makes Good ignorant of erōs.
} 
good man's house ( $174 \mathrm{a}-\mathrm{b})$, and, given that Agathon is Pausanias' eromenos, this characterization of Agathon may further bolster the thesis that Erōs has beneficial effects on the soul.

On the other hand, consider the drunk and disorderly Alcibiades. Alcibiades has heard Socrates' logoi and says that their effect is like being possessed by a divine spirit or being intoxicated (215c-e). But Alcibiades finds them upsetting insofar as they make him radically re-evaluate his values, feeling as though his life "was no better than the most miserable slave's" (215e). Socrates causes Alcibiades to say that "all that matters is just what I most neglect: my personal shortcomings, which cry out for the closest attention" (216a). But rather than embracing these truths, Alcibiades refuses to listen and runs off, as if he were being drawn into impending doom by the sweet sounds of the Sirens (216a). Indeed, he says he wants Socrates to die but also knows that he cannot live without him, so torn up and confused is he over this man (216c). Socrates makes Alcibiades feel shame in the way Phaedrus detailed, but it is transitory in that Alcibiades only feels it when he is around Socrates. Alcibiades cannot prove Socrates wrong, yet goes back to his old ways "in [his] desire to please the crowd" the moment he leaves Socrates' side (216b). Alcibiades is occasionally purged of his false beliefs but he somehow doesn't get Socrates' point and cannot sustain a character change once he is pressured by the crowd. When Alcibiades is with Socrates he says that "nothing is more important to me than becoming the best man I can be" (218d), but these values do not remain fixed in his soul.

Alcibiades' changing ways are contrasted with Socrates' steadfast virtue. Socrates is surrounded by beautiful boys but considers their beauty, along with their fame and wealth, "beneath contempt" (216d-e), and resists Alcibiades' advances (217a-219c). To Socrates' temperance, Alcibiades praises his bravery (219e-22Id), and says that his arguments are "worthy of a god, bursting with figures of virtue inside... of the greatest importance for anyone who wants to become a good man (kalöi kagathöi)" (222a). The dialogue closes with Socrates arguing till dawn and then going off to the Lyceum to "spend the rest of the day just as he always did," while the other guests rested (223d). Socrates is totally dedicated to philosophy in a way that Alcibiades clearly is not, which is why only Socrates can make philosophical progress. Alcibiades cares about philosophy while Socrates is around, but Socrates, barely human and quasi-divine, continues his lifestyle through rain, cold, and snow, and when everybody else needs to sleep. 
Philosophy without erotic dedication can do more harm than good, and those with conflict between different motivations in their soul will not make progress on the ascent. Alcibiades embodies this: he hates being corrected, despite recognizing the truth that Socrates reveals to him (cf. Rep. 476d). Thus while Alcibiades can speak the truth, he does not love it and he does not live in accordance with it. He does not have the kind of soul necessary for grounding a complete commitment to philosophy. Only those with souls as stable as Socrates can move up the ascent. ${ }^{29}$

29 Thanks to Pierre Destrée, Radcliffe Edmonds, Zina Giannopoulou, David Halperin, Emily Hulme, Noelle Lopez, M.M. McCabe, Jessica Moss, Alexander Nehamas, Suzanne Obdrzalek, Anthony Price, Frisbee Sheffield, Nick Smith, Franco Trivigno, and Paul Woodruff for their comments on earlier drafts of this chapter. Special thanks are due to Julia Annas, Tom Hercules Davies, Rachana Kamtekar, and Josh Wilburn for their extensive help and detailed comments at numerous points during the course of this project. I am also grateful to audiences at the Society for Ancient Greek Philosophy Annual Meeting at Fordham University, Oct. 20I4, and the Princeton Graduate Philosophy Colloquia. 